ONDŘEJ ŠERÝ

Masaryk University, Czech Republic

\title{
The impact of economic crisis on regions dominated by motor vehicles industry (the case of Vysočina Region)
}

Since 2008 the world economy has been considerably affected by the global economic crisis, including the Czech Republic as well. According to many authors it was the most serious economic downturn since the Second World War, actually since the 30 s of the $20^{\text {th }}$ century, when the world was hit by the global economic crisis. In the second half of the $20^{\text {th }}$ century several economic crises occurred. Still they were more or less locally limited. The economic crisis was relatively strongly reflected in the industry. The decline in industrial production and fewer orders led to operational shutdowns, redundancies, wage cuts and other anti-crisis and economical measures. It subsequently caused lower demand of industrial companies and citizens for services, which meant that another important economic sector was affected by the crisis.

\section{A BRIEF REVIEW OF THE LITERATURE FOCUSING \\ ON THE CRISIS AND THE AUTOMOTIVE INDUSTRY}

Large companies in the automotive industry and their impact on regional development are studied by geographers at Charles University in Prague and Masaryk University in Brno. The attention of Prague geographers is logically focused on the role of Škoda Auto, based in Mladá Boleslav (e.g. Pavlínek 2003; Pavlínek, Janák 2007; Pavlínek, Ženka 2010). The geographers at Masaryk University have been systematically studying Bosch Diesel Company, based in Jihlava (Toušek, Tonev 2002; Kunc 2006; Novák 2007; Toušek, Novák 2009; Šerý 2010).

The topic of the impact of global economic crisis, for obvious reasons, has been present in literature for the last two years. We can mention the work written by Dubská (2009) on the impact of the crisis on Czech industry. The aim of the paper written by Lauko, Križan and Gurńák (2009) is to show diminishing regional disparities on the labour market due to the crisis. The interviews with the world economists (often the Nobel prize winners) are presented by Kovanda (2010) and Sedláček (2009) and they deal with the issue from philosophical and economic perspective. 


\section{The Automotive Industry}

The automotive industry is one of the fundamental sectors of the world economy. And this sector, which previously recorded the highest dynamic range, experienced one of the largest declines during the crisis. (Dubská, 2009, 425-426). The Czech economy has specialized in the automotive industry for a long time, although many experts disagree about that. Their concerns could be supported by the data. Only in 2008, when the crisis came up in the last quarter of the year, the Automotive Industry Association member companies participated in total industrial production in terms of revenue by $19 \%$ and in total export of the Czech Republic by $18,7 \%$. On $31^{\text {st }}$ December 2008 these companies employed 127,439 people.

Figure 1 illustrates the Czech specialization in automotive industry. Other major automakers that produce the most cars per capita are Slovakia and Slovenia, even when compared to big car producers such as Germany, France, Spain, the UK or Russia.

Tab. 1. The number of cars produced per 1000 inhabitants in European countries in 2008

\begin{tabular}{|l|l|c|l|l|c|}
\hline No. & \multicolumn{1}{|c|}{ Country } & $\begin{array}{c}\text { Number } \\
\text { of produced cars } \\
\text { per 1 000 inhabitants }\end{array}$ & No. & \multicolumn{1}{|c|}{ Country } & $\begin{array}{c}\text { Number } \\
\text { of produced cars } \\
\text { per 1 000 inhabitants }\end{array}$ \\
\hline 1. & Slovakia & 106,6 & 11. & Poland & 21,7 \\
\hline 2. & Slovenia & 98,4 & 12. & Austria & 17,2 \\
\hline 3. & Czech Republic & $\mathbf{9 0 , 0}$ & 13. & Italy & 11,3 \\
\hline 4. & Germany & 64,9 & 14. & Portugal & 10,8 \\
\hline 5. & Belgium & 64,5 & 15. & Romania & 10,7 \\
\hline 6. & Spain & 47,2 & 16. & Russia & 9,4 \\
\hline 7. & France & 35,2 & 17. & Netherlands & 3,6 \\
\hline 8. & Hungary & 34,0 & 18. & Finland & 3,3 \\
\hline 9. & Sweden & 28,0 & 19. & Ukraine & 3,0 \\
\hline 10. & United Kingdom & 23,7 & 20. & Serbia & 1,4 \\
\hline
\end{tabular}

Source: Automotive Industry Association, 2009, Automotive industry statistics of the Czech Republic 20042008. Praha + own calculations

There are three major automotive companies in the Czech Republic - Škoda Auto a.s. Mladá Boleslav, TPCA Czech s.r.o. Kolín and Hyundai Motor Manufacturing Czech s.r.o. Nošovice. In 2008 these companies produced 934,032 cars and a year later, despite the ongoing economic crisis, the production was even higher - 970,410 cars (Automotive Industry Association, 2010, 128). 
Tab. 2. The number of cars produced in the companies in the Czech Republic in yars 2004-2009

\begin{tabular}{|l|c|c|c|c|c|c|}
\hline & 2004 & 2005 & 2006 & 2007 & 2008 & 2009 \\
\hline Škoda Auto & 442796 & 492948 & 555132 & 616573 & 597693 & 519921 \\
\hline TPCA Czech & & 103819 & 293650 & 308478 & 324289 & 332489 \\
\hline Hyundai M. M. Czech & & & & & 12050 & 118000 \\
\hline Total & $\mathbf{4 4 2 ~ 7 9 6}$ & $\mathbf{5 9 6 7 6 7}$ & $\mathbf{8 4 8} \mathbf{7 8 2}$ & $\mathbf{9 2 5} \mathbf{0 5 1}$ & $\mathbf{9 3 4} \mathbf{0 3 2}$ & $\mathbf{9 7 0} \mathbf{4 1 0}$ \\
\hline
\end{tabular}

Source: Sdružení Automobilového Průmyslu 2010, Automotive Industry Association, 2010, Automotive Industry Statistics of the Czech Republic 2004-2009, Praha

The history of Škoda Auto goes back to 1895 when the company Laurin \& Klement was set up in Mladá Boleslav and began to manufacture cars in 1905. It was merged with Škoda Plzeň in 1925. After the Second World War it was separated from Škoda Plzeň's section and transformed into AZNP Mladá Boleslav (Automobile Production Plants, National Corporation) and became the monopoly producer of personal motor cars in former Czechoslovakia. After 1989 the company started using its original name again and its strategic foreign trading partner, German concern Volkswagen, joined the company in 1991. Volkswagen steadily increased its share and finally, in 2000, it gained control of Škoda Auto. Today the company has three production plants. The basic plant is located in Mladá Boleslav (Central Bohemian Region) and about 20,000 people are employed there. The other two plants are in Hradec Králové Region. There are about 1,200 employees in Vrchlabí (District Trutnov) and about 2,500 people are employed in Kvasiny (District Rychnov nad Kněžnou). Due to the economic crisis Škoda Auto produced about 80,000 cars less than last year, there were some operational shutdowns and the normal work weak was shortened to four days for several months. The company took advantage of the introduction of vehicle scrappage in some European countries, especially in Germany in 2009. In spite of that, the company had to lay off more than 3,000 workers. In the second half of 2010 the situation has improved and some workers have been hired again.

The firm TPCA Czech Kolín (Toyota Peugeot Citroën Automobile) is the joint-venture of two companies, Toyota Motor Corporation and PSA Peugeot Citroën. The construction of the company started in 2001 in the industrial zone Kolín-Ovčáry (The Central Region), which became the state subsidized area for this purpose. The production began in February 2005 and has reached the planned annual production capacity of 300,000 cars. Nowadays, the company has about 3,500 employees. The scrappage introduced as an anti-crisis measure significantly helped the Kolín Company as it is focused on the production of small ecological cars, which have been targeted by the scrappage. This enabled TPCA to hire about 100 new workers in 2009 and some extra shifts could be created. Therefore the company was able to produce about 8,400 vehicles more than in 2008 .

The youngest car factory in the Czech Republic is Hyundai Motor Manufacturing Czech, based in the state subsidized industrial zone in the North Moravian Nošovice (District Frýdek-Místek). The production plant was established in 2006 and the mass production in the originally South Korean car factory was launched in November 2008, in time of the first more significant impacts of the crisis in the Czech Republic. The company employs about 2,200 people. Despite the increasing production of vehicles the company's results were 
worse than expected because of the economic crisis and Hyundai suffered a loss of almost two billion euros in 2009. The true cost from last year, however, suggests an entirely different positive reality. A three-shift system, the production capacity of 300,000 vehicles and 3,500 employees are planned in 2011.

\section{The SITUATION IN Vysočina Region}

Automakers are not the only employers in the automotive industry -tens of thousands of jobs are created by their subcontractors. This paper further deals with the impact of the economic crisis in Vysočina Region. The subcontractors of car companies represent the largest group of employers in the region, not only in the processing industry but also in the economy as a whole. We could mention Automotive Lighting s.r.o. Jihlava, Bosch Diesel s.r.o. Jihlava, Draka Kabely s.r.o. Velké Meziřŕčí, Futuba Czech s.r.o. Havlíčkův Brod, ITW Pronovia a.s. Velká Bíteš, Mann + Hummel (CZ) s.r.o. Nová Ves, Moravské kovárny a.s. Jihlava, Motorpal a.s. Jihlava, První brněnská strojírna Velká Bíteš a.s. or Valeo Compressor Europe s.r.o. Humpolec.

The economic crisis has obviously affected the rate of unemployment. Fig. 1 shows that a large number of subcontractors in this region caused that unemployment in Vysočina Region exceeded the unemployment rates of the whole country. However, it is rather the opposite. The two indicators got near with the improving state of the Czech economy and it can be assumed that if positive developments continue, the unemployment in the Czech Republic will be again higher than in Vysočina Region.

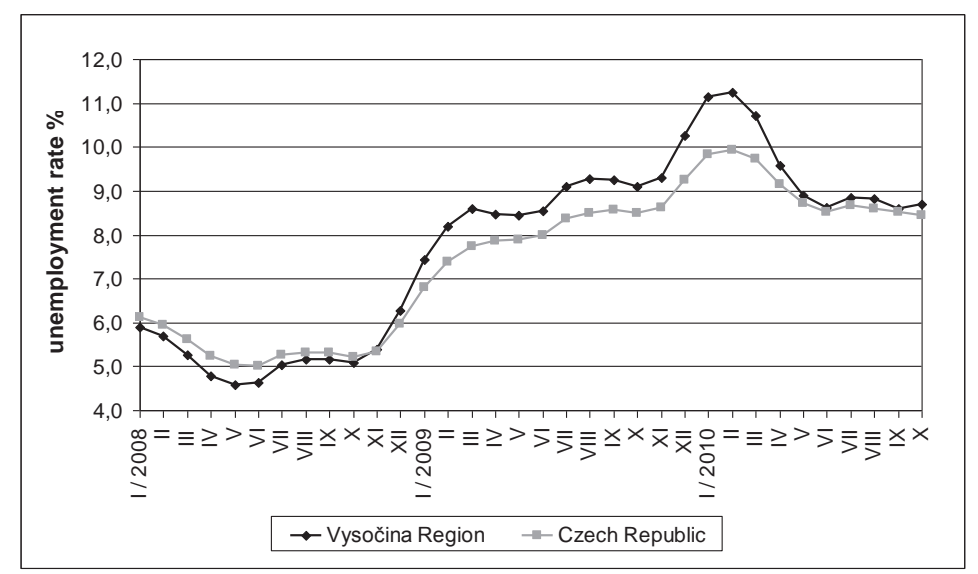

Fig. 1. The trend of unemployment rate in Vysočina Region and Czech Republic in the period from january 2008 to october 2010

Source: Ministry of Labour and Social Affairs of the Czech Republic - Employment Portal, 2010

The region's (and its districts) high dependence on the subcontracting companies to the automotive industry can be measured by placing the region and its districts among 14 regions of the Czech Republic, respectively among 77 districts, ranked according to unemployment 
rates. When considering the regions, the dependence (measured by this method) was still not clearly evident. Throughout the period which we consider (from January 2008 to October 2010) the Vysočina Region occupied the seventh position among the regions in terms of unemployment; except for few months (form December 2008 to March 2009) when it dropped by one position (this period coincides with redundancies in the largest subcontracting companies in the region). In case of Jihlava District, where the important companies Bosch Diesel, Automotive Lighting or Motorpal are based, a strong relationship between the economic situation of these companies and the district's ranking among all Czech districts was proved (according to the unemployment rate). Fig. 2 shows more details.

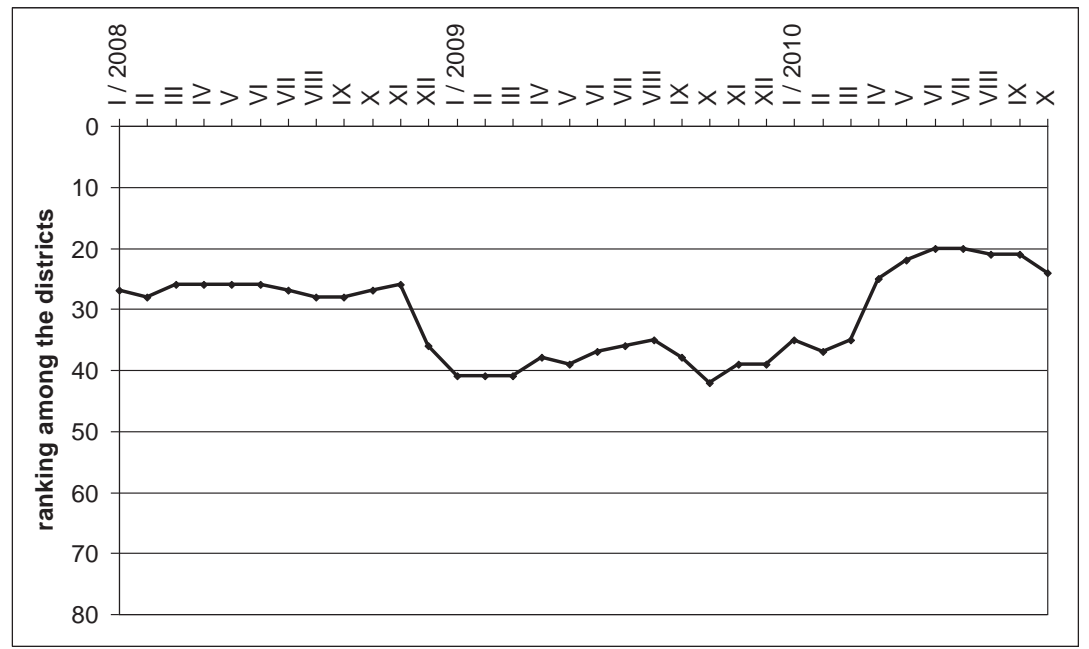

Fig. 2. The trend of Jihlava district's ranking among all Czech districts (77 units) according to unemployment rate in the period from january 2008 to october 2010

Source: Ministry of Labour and Social Affairs of the Czech Republic - Employment Portal, 2010

While before the crisis the Jihlava District was around the $26^{\text {th }}$ place, after the first wave of lay-offs in December 2008 it fell to the $36^{\text {th }}$ place and in the first months of 2009 it was even on the $41^{\text {st }}$ place. The situation on the automobile market began to improve in the first quarter of 2010, which was clearly reflected in the shift to the $25^{\text {th }}$ place and then in the following months to the $20^{\text {th }}$ place. The position of the Jihlava District among the Czech districts, in terms of employment, is now even better than before the crisis.

\section{The IMPACT OF THE ECONOMIC CRISIS UPON Bosch Diesel S.R.O. JiHLAVA}

Among Jihlava based companies, Bosch Diesel s.r.o is the largest employer in Vysočina Region. The company manufactures components for diesel engines. Bosch Diesel is part of the German group Robert Bosch GmbH. It came to Jihlava in 1993 and established a joint venture with Motorpal (Bosch Diesel purchased its share three years later). The company gradually expanded and now it operates three production plants there (the significant turning 
point were especially extensive investments in 2001). The plant I is responsible for diesel pumps repair series. The plant II deals with the production of high-pressure tanks, so-called rails, through which fuel is injected into the engine. The high-pressure diesel pumps are manufactured in the plant III.

The first signs of the crisis were reflected by Bosch Diesel in 2008, when a few American clients cancelled their orders and first operational shutdowns followed. At that time the company had the highest number of employees since its establishing in Jihlava, 6,347 people. The situation deteriorated further in July and August 2008. There was no work for some employees so they had to stay home for $80 \%$ of salary. The company ceased to renew fixedterm contracts, with few exceptions. Expensive oil and unfavourable exchange rates caused harm to the company too (it resulted in price increases of its products abroad and undermined the competitiveness). Nevertheless the production of new pumps CP4 was launched and it was expected to increase annual production (although estimates have been decreased).

There were first redundancies in the late October because of the low utilization percentage (the company did not want to create any warehouse stock). Finally, 29 assembly workers were affected adversely by this measure. Bosch claimed the situation to be a natural market swing. However, the number of negotiated contracts was decreasing in the first quarter of 2009 and the second wave of lay-offs was unavoidable. This time Bosch dismissed 125 employees (workforce) by the end of November. Both groups of the released were paid a severance pay in accordance to seniority in the company - from three to six times of average wages. Shifts began to be planned only for a month; more irregular fluctuations in the production appeared.

The economic crisis had deepened further so the third wave of dismissals was announced - 343 employees were put out of work by the end of 2008 . According to the head of HR Department several aspects were taken into account when considering people to be released - working output, discipline at work and whether the position is sustainable in the future. On the other hand, the sickness rate had no importance. But yet some objections from labour unionists appeared because none of them was asked to consult the lists of the released workers. Bosch set up some other measures to improve its economic state. By the end of the year the production was stopped several times, the shifts layout was changed (from twelve hours to eight hours) and since January 2009, the so far continuous operation was converted into six days with Sundays off. At that time, Bosch still employed about 5,900 people. The loss of workers, among other things, had bad impact on the Jihlava's public transport, which recorded about $15 \%$ lower sales. The reflections on company's kindergarten were also halted by the crisis. The wages of workers rose by $8,6 \%$ since January 2009 , but it was the result of the collective agreement signed for two years, not a good economic situation of the company.

The introduction of scrappage had almost no effect in many European countries (only in Germany it helped to a short business recovery after summer holidays in 2009). Bosch Diesel would much rather welcome a change of laws governing so-called Working Time Accounts (WTA). This measure allows the staff to do extra hours when there is plenty of work and during its absence to stay at home. The salary received should be fixed all the time. The "adjustment period" (the period for which the extra hours must be done) is too short in the Czech Republic according to representatives of Bosch Diesel - only 52 weeks in comparison to 4 years in Slovakia, and in Germany it is even possible for the whole duration 
of the employment. For this reason it was not established in the Jihlava plants. The company would accept at least four years after the model of Slovakia.

Over the summer holidays in 2009, the decline in production slowly began to stop. Other measures used by Bosch, were educational and training courses. About 635 employees took part in the project “Educate Yourself”, subsidized by the European Union. In July 2009, the four-day week was extended until the end of March 2010 (the day-offs workers were paid $75 \%$ of salary and received extra money for any work at the weekends) and no collective redundancies were promised by this date.

At the end of July a forced outage threatened Bosch due to the fall of its subcontractor Magneton. The subcontractor was responsible for the surface finishing of rails (fuel storage tanks), production of which involves approximately 500 people in Bosch. Bosch considered funding of Magneton as it had no alternate subcontractor. The financial loss caused by Magneton's breach of contract was estimated at 3,3 million euros per month. The change of the supplier was eventually successfully completed, but it required time-consuming testing and customer approval process. The possibility of voluntary redundancy and the severance pay of eight average salaries were terminated in late August. This measure was put into practise in February 2009 and the number of salaries started to grow. At first there were two salaries, then three, then five and finally eight average salaries. About 1,000 employees took advantage of it and because of the great interest it had to be stopped. Such popularity was not expected by the HR Department. The total number of workers dropped to about 4,600 people.

In autumn some plants have returned to the five-day work week (even thou, according to the agreement, the model of shortened week could be used until the end of March 2010). In the last months of 2009, the number of orders increased so much that part of the production had to be in operation even over the Christmas holidays. The decline in number of employees was stopped too. The absolute minimum was reached in December 2009 (4,180 workers). Since then Bosch began to hire new employees and today the company is operated by about 5,000 workers. The number of employees in specific months during the global economic crisis is shown in fig. 3 .

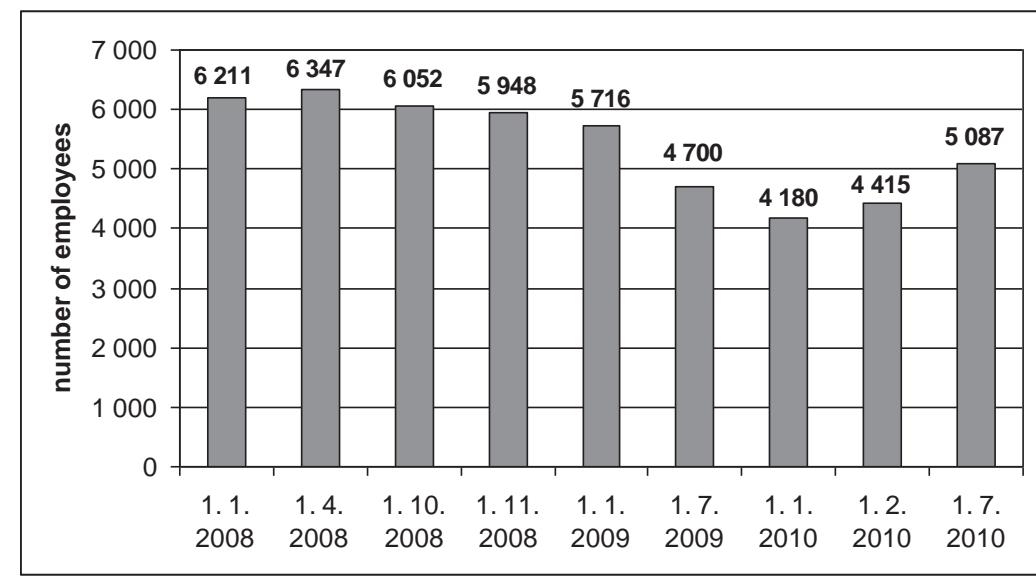

Fig. 3. The number of Bosch Diesel employees during the global economic crisis 
In the next few years Bosch Diesel plans to stabilize the number of employees to about 5,000 people, which is considered optimal. The factory was originally built for 9,000 workers but it was not possible to employ so many people. There is strong competition in the area, especially from Automotive Lighting, Motorpal and Moravské kovárny. With modernization of pumps, machinery automation and robotics the labour demand is increasing and eventually the skills become more important nowadays.

During the economic crisis the concerns about the possible departure of Bosch Diesel to another area have intensified. The company resolutely denied such considerations. While moving, the company could take advantage of cheaper, but relatively unskilled labour. Currently, the proximity to customers, logistics and communication are of great importance, which the countries lying east of the Czech Republic are unable to offer. Top executives also claim that they invested a large sum of money into the Jihlava Company and therefore it is one of the most important and most modern factories manufacturing the pumps for diesel engines in the world.

\section{CONCLUSION}

The economic crisis has clearly demonstrated the risks of the specialization of the Czech economy in the automotive industry. It brings significant profits and jobs for many people but on the other hand, during the economic recession, great economical losses were evident, especially at the regional level. Diversification of industrial structure would undoubtedly lead to the more stable and sustainable industry in the Czech Republic. Other trends that would reduce the negative impact of the economic crisis seem to be: value-added production, science and research and leaving at least part of the decision-making power to individual companies (to avoid any outer supervision). These mechanisms are supposed to have a positive effect, especially when times are tough.

\section{The impact of economic crisis on regions dominanted by motor vehicles industry (the case of Vysočina Region)}

The Czech economy has been significantly affected by the global economic crisis since the second half of 2008. The Czech economy is strongly dependant on the motor vehicles industry, the sector severely hit by the crisis. There are not only three major automobile companies in the Czech Republic (Škoda Auto Mladá Boleslav, TPCA Czech Kolín and Hyundai Motor Manufacturing Czech Nošovice), but there are also many subcontractors. The Vysočina Region, the model territory used in this article, has several such major companies. This fact had quite a significant impact on the economic situation in the Vysočina Region during the crisis. The paper also examines individual anti-crisis measures adopted by the largest subcontractor to the motor vehicle industry in the region, Bosch Diesel s.r.o. Jihlava.

This paper was elaborated under the students' support project at the Faculty of Science, "Strengthening and Improving Students Creative Work in the Fields of Mathematics, Physics and Earth Science "(KVAS-MPG). The project is funded by Masaryk University and it is aimed at supporting student projects at MU (MUNI/A/1060/2009). 


\section{References}

Dubská D., 2009, Český průmysl v době nastupující recese. Statistika: ekonomicko-statistický časopis. Vol. 46, No. 5, pp. 423-445.

Kovanda L., 2010, Přiběh dokonalé bouře a hovory (nejen) s laureáty Nobelovy ceny o finanční krizi. Knižní edice Týden 1/2010. Mediacop, Praha, 112 pp.

Kunc, J., 2006, Bosch Diesel - Not only an Industrial Phenomenon in the Vysočina Region (Czech Republic). Moravian Geographical Reports. Vol. 14, No. 1, pp. 29-37.

Lauko V., Križan F., Gurňák D., 2009, Časovo-priestorové aspekty nezamestnanosti na Slovensku $v$ procese ekonomickej transformácie a krízy. In V. Klímová (ed.): XII. mezinárodní kolokvium o regionálních vědách. Masarykova univerzita, Brno. pp. 58-65.

MPSV ČR, 2010, Portál zaměstnanosti [online]. MPSV ČR, Praha. Dostupné na: <http://portal.mpsv. $\mathrm{cz} / \mathrm{sz} / \mathrm{stat} / \mathrm{nz}>$.

Pavlínek P., 2003, Transformation of the Czech Automotive Components Industry Through Foreign Direct Investment. In: Eurasian Geography and Economics. Vol. 44, No. 3, pp. 184-209.

Pavlínek P., Janák L., 2007, Regional Restructuring of the Škoda Auto Supplier Network in the Czech Republic. European Urban and Regional Studies. Vol. 14, No. 2, pp. 133-155.

Pavlínek P., Ženka J., 2010, Upgrading in the automotive industry: firm-level evidence from Central Europe. Journal of Ecomic Geography. pp. 1-28.

Sedláček T., 2009, Ekonomie dobra a zla: Po stopách lidského tázáni od Gilgameše po finančni krizi. 1. vyd., 65. pole, Praha. 270 pp.

Sdružení Automobilového Průmyslu, 2009-2010, Statistika automobilového průmyslu ČR 2004-2009. SAP, Praha. 154 pp.

Šerý O., 2010, Český prìmysl po roce 1989 (s důrazem na období globální ekonomické krize). Diplomová práce. Brno: Masarykova univerzita. $107 \mathrm{pp}$.

Toušek V., Novák V., 2009, Jihlava - the Centre of the Vysočina Region and Foreign Investments. Acta Universitatis Palackianae Olomucensis. Facultas Rerum Naturalium - Geographica. Vol. 40, No. 1, pp. 45-66.

Toušek V., Tonev P., 2002, Jihlava: pól hospodářského rozvoje kraje Vysočina? In O. Milerski, K. Skokan (ed.): Regionální politika kandidátských zemí před vstupem do Evropské unie. Ostrava: Ekonomická fakulta VŠB - TU, pp. 214-220.

Mgr Ondřej Šerý, student of the Ph.D. program Regional Geography and Regional Development Masaryk University, Brno, Czech Republic

Faculty of Science

Department of Geography

e-mail: ondrej.sery@mail.muni.cz 